\title{
FAKTOR YANG MEMENGARUHI FINANCIAL SATISFACTION PENGGUNA E- COMMERCE DI SURABAYA
}

\author{
Moch. Sigit Prabowo \\ Universitas Negeri Surabaya \\ moch.prabowo16080574086@mhs.unesa.ac.id \\ Nadia Asandimitra \\ Universitas Negeri Surabaya \\ nadiaharyono@unesa.ac.id
}

Abstract

The use of the internet has now become a necessity in everyday life. E-commerce is the sale, purchase, marketing of goods or services through electronic systems or the internet. This study aims to determine the effect of financial literacy and financial attitude on financial management behaviour as a mediator for e-commerce users in Surabaya. The type of data used in this study is quantitative data and uses primary data. The number of samples used was 218 respondents with criteria for ecommerce users included in the top 10 e-commerce that dominated the Indonesian online market, residing in the city of Surabaya, and aged 18 to 35 years. This study's data collection instrument was the distribution of questionnaires online. The data analysis technique in this research uses the Path Analysis technique of the Complex Model using AMOS version 23. The results of this study are that financial literacy influences financial management behaviour. Financial attitude does not affect financial management behaviour because based on age that is still not fully able to manage their finances very well. Financial literacy and financial management behaviour affect financial satisfaction. Financial attitude does not affect financial satisfaction because respondents still do not have their income or their income level is not too high. Financial management behaviour mediates financial literacy for financial satisfaction. Financial management behaviour does not mediate financial attitude towards financial satisfaction.

Keywords: financial attitude; financial literacy; financial management behaviour; financial satisfaction.

\section{PENDAHULUAN}

Kemajuan teknologi informasi dan komunikasi yang ditandai dengan kehadiran internet telah mempermudah manusia untuk mencari, menerima dan menyebarluaskan informasi tanpa terikat batas dan jarak. Penggunaan internet kini telah menjadi kebutuhan dalam kehidupan sehari-hari sebagian besar masyarakat dunia. Hal ini dimanfaatkan manusia dalam bidang ekonomi yaitu sistem jual beli secara online atau e-commerce. E-commerce adalah metode pembelian atau penjualan suatu produk menggunakan bantuan internet. Dengan adanya sistem ini, penjual dan pembeli tidak perlu bertemu secara langsung untuk melakukan sebuah transaksi. Penggunaan e-commerce di dunia semakin bertambah dari tahun ke tahun. Negara-negara di kawasan Asia adalah pengguna yang terbanyak. Tahun 2017, jumlah transaksi di wilayah Asia yaitu \$1052,90, Amerika Utara \$660,40, Eropa Barat $\$ 432,60$, Eropa tengah dan timur $\$ 73,10$, Amerika Latin $\$ 74,60$, dan Timur Tengah dan Arika $\$ 51,40$ (Vpnmentor.com, 2019). Pangsa pasar atau GMV e-commerce di kawasan Asia Tenggara adalah US\$ 38,2 miliar. GMV e-commerce di Indonesia tahun 2019 merupakan yang tertinggi di Asia Tenggara dengan nilai US\$20,9 miliar (Google, Tamasek, \& Bain \& Company, 2019).

Menurut survey Priceza (2018), Kota Jakarta, Surabaya, Medan, Bandung, dan Makassar merupakan lima kota yang mempunyai kunjuang terbanyak pengguna e-commerce di Indonesia. Surabaya selalu menjadi salah satu kota dengan kunjungan e-commerce terbanyak di Indonesia dan selalu mengalami peningkatan pada setiap tahun dengan jumlah kunjungan sebanyak 12,36\% tahun $2015,17,42 \%$ tahun 2016 dan 20,90\% tahun 2017. Perkembangan e-commerce ini memberikan kemudahan bagi 
masyarakat untuk melakukan aktivitas penjualan dan pembelian. Dengan memanfaatkan e-commerce, masyarakat bisa menjangkau produk dengan luas, memperoleh informasi tentang produk dengan mudah dan cepat, dan berkomunikasi dengan penjual dengan mudah. Hal ini sangat mendukung terjadinya peningkatan perilaku konsumtif masyarakat (Rizkiawati \& Asandimitra, 2018).

Pengeluaran per kapita masyarakat Jawa Timur tahun 2018. Kota Surabaya berada pada posisi teratas di Jawa Timur dengan pengeluaran per kapita sebesar Rp17.157.000 (BPS Jatim, 2019). Menurut BPS Jatim (2019), tingkat pengeluaran masyarakat Kota Surabaya selalu terjadi peningkatan pada tahun 2010 sampai 2018. Pengeluaran per kapita pada masyarakat Kota Surabaya yang tergolong tinggi berarti menunjukkan bahwa masyarakatnya masih memiliki sifat konsumtif dilihat dari tingginya ratarata pola konsumsi rumah tangga secara umum (Armilia \& Isbanah, 2020). Karena berbagai uraian di atas maka dipilih Surabaya sebagai objek dalam penelitian ini. Menurut Rizkiawati \& Asandimitra (2018), ketika masyarakat mampu melakukan pengelolaan keuangan dengan baik tentu mereka akan memberikan batasan untuk pengeluaran dari pendapatan yang mereka miliki sehingga pengeluaran akan terkontrol dan dampaknya masyarakat akan terhindar darisifat konsumtif. Pengelolaan keuangan yang baik sangat dibutuhkan oleh masyarakat untuk menunjang dan mendukung pemerintah dalam menciptakan kesejahteraan masyarakatnya. Dimulai dari individu masyarakat itu sendiri untuk dapat mengelola apa yang mereka miliki untuk selanjutnya dapat menunjang ke dalam kehidupannya. Perilaku pengelolaan keuangan yang tepat dapat dijadikan sebagai modal untuk mencapai kepuasan keuangan (Armilia \& Isbanah, 2020).

Ada berbagai komponen yang berhubungan dengan kepuasan keuangan. Faktor yang pertama adalah financial literacy. Financial literacy adalah pengetahuan mendasar yang dibutuhkan untuk mengatur keuangan pribadi yang sukses (Anggraeni, 2019). Individu apabila memiliki literasi keuangan yang tinggi maka akan memiliki pengetahuan atau pemahaman mengenai bagaimana melakukan manajemen keuangan yang baik serta mengetahui produk-produk keuangan dan memahami bagaimana cara menggunakannya (Humaira \& Sagoro, 2018). Literasi keuangan memberi keterampilan menerapkan pemahaman itu dalam kehidupan sehari-hari untuk mencapai kesuksesan di kemudian hari. Itulah alasan mengapa ada peningkatan kehidupan karena kepuasan yang datang dari finansial literacy yang tinggi (Armilia \& Isbanah, 2020). Menurut Ahmad et al. (2017), financial literacy berpengaruh positif terhadap financial satisfaction. Hasil yang sama juga diungkapkan Hasibuan et al. (2018) dan Falahati et al. (2012). Hasil berbeda diungkapkan oleh Yap et al. (2018), bahwa financial literacy tidak berpengaruh terhadap fianancial satisfaction.

Faktor berikutnya yang berhubungan dengan kepuasan keuangan yaitu financial attitude. Menurut Arifin (2018), financial attitude memiliki peran penting dalam menentukan keberhasilan atau kegagalan perilaku finansial. Semakin tinggi sikap keuangan seseorang, maka semakin tinggi pula kesadaran untuk bertanggung jawab atas penggunaan keuangannya, sehingga akan berdampak positif pada perilaku manajemen keuangan. Seseorang apabila mempunyai financial attitude yang baik mampu menahan diri dalam melakukan kegiatan konsumsi dan memiliki kontrol yang baik terhadap perilaku keuanggannya. Apabila individu memiliki perilaku pengelolaan finansial dengan baik akan mencapai kepuasan keuangan (Candra \& Memarista, 2015). Menurut Arifin (2018), financial attitude berpengaruh terhadap financial satisfaction. Hasil yang sama diungkapkan Candra \& Memarista (2015). Hasil yang berbeda didapatkan oleh Armilia \& Isbanah (2020), bahwa financial attitude tidak berpengaruh terhadap financial satisfaction.

Faktor berikutnya yang juga berhubungan dengan kepuasan keuangan adalah financial management behavior. Financial management behavior ialah keterampilan individu dalam merencanakan, menganggarkan, mengelola, dan mengendalikan keuangannya (Anggraeni, 2019). Apabila individu memiliki perilaku manajemen keuangan yang baik, seseorang tersebut akan mencapai kesejahteraan individu dan memperoleh kepuasan keuangan. Hal ini menunjukkan bahwa semakin tinggi tingkat financial management behavior seseorang, maka semakin tinggi kepuasan keuangan yang dirasakan seseorang (Hasibuan et al., 2018). Menurut Yap et al. (2018), financial management behavior berpengaruh positif terhadap financial satisfaction. Hasil yang sama juga diungkapkan oleh Hasibuan 
Moch. Sigit Prabowo \& Nadia Asandimitra. Faktor yang Memengaruhi Financial Satisfaction Pengguna E-Commerce di Surabaya

et al. (2018) yang mengemukakan bahwa financial management behavior berpengaruh signifikan terhadap financial satisfaction. Penelitian ini bertujuan untuk menguji pengaruh financial literacy dan financial attitude terhadap financial satisfaction dengan financial management behavior sebagai variabel mediasi pada masyarakat pengguna e-commerce di Kota Surabaya.

\section{KAJIAN PUSTAKA DAN PENGEMBANGAN HIPOTESIS}

\section{Theory of Planned Behavior (TPB)}

Theory of planned behavior dikemukakan Profesor Icek Ajzen. Teori ini merupakan teori yang membahas mengenai perilaku seseorang berada dalam kontrol atau kendali individu itu sendiri. Theory of planned behavior menjelaskan jika latar belakang seseorang dalam melakukan perilakunya dipengaruhi oleh faktor-faktor yang melatarbelakanginya yaitu attitude towards behavioral, subjective norm, dan perceived behavioral control. Attitude towards behavioral adalah faktor yang ditentukan oleh pandangan seseorang tentang apa yang akan terjadi jika melakuakan sebuah tindakan tertentu. Apabila seseorang meyakini bahwa perilaku tersebut memberikan keuntungan, maka keyakinan itu bisa memperkuat sikap seseorang terhadap perilaku itu sedangkan apabila perilaku tersebut mengakibatkan keburukan atau kerugian maka seseorang akan menghindari perilaku itu. Subjective norm adalah faktor yang memengaruhi perilaku seseorang yang bersumber dari orang-orang terdekat, misalnya keluarga, teman, atau kerabat. Perceived behavioral control merupakan faktor yang memengaruhi perilaku seseorang yang berdasarkan pandangan seseorang mengenai kemudahan dan hambatan dalam mewujujudkan sebuah perilaku. Faktor ini ditentukan oleh ketersediaan sumber daya antara lain peralatan yang menunjang dan keterampilan untuk melakukan hal tertentu (Ajzen, 2005).

\section{Subjective Well-Being}

Teori subjective well-being merupakan teori yang dikemukakan Profesor Edward F. Diener. Subjective well-being seseorang berhubungan dengan suatu perasaan serta penilaian seseorang terhadap suatu hal yang telah mereka alami. Subjective well-being mempunyai tiga faktor utamayaitu kepuasan, efek menyenangkan dan efek tidak menyenangkan. Faktor-faktor utama tersebut dapat dibagi lagi menjadi beberapa dimensi. Dimensi yang berhubungan dengan faktor kepuasan antara lain perasaan cinta, pertemanan, dan hubungan keluarga. Dimensi yang berhubungan dengan efek menyenangkan adalah emosi yang sifatnya menyenangkan yang dirasakan oleh seseorang, misalnya kebahagiaan, harga diri, keberhasilan dan pencapaian. Dimensi yang berhubungan dengan efek tidak menyenangkan adalah emosi yang sifatnya tidak menyenangkan yang dirasakan oleh seseorang, misalnya marah, malu, sedih, ketakutan, kegelisahan, depresi, dan kesepian. Apabila seseorang lebih sering merasakan hal-hal yang menyenangkan dari pada hal-hal yang tidak menyenangkan, maka individu tersebut dapat dikatakan telah mencapi kepuasan. Sedangkan apabila seseorang lebih sering merasakan hal-hal yang tidak menyenangkan dari pada hal-hal yang menyenangkan, maka individu tersebut dapat dikatakan belum mencapai kepuasan (Diener et al., 2003).

\section{Financial Literacy}

Financial literacy adalah pemahaman mendasar yang dibutuhkan dalam mengatur keuangan pribadi yang sukses (Anggraeni, 2019). Individu apabila memiliki literasi keuangan yang tinggi akan memiliki pengetahuan atau pemahaman mengenai bagaimana melakukan manajemen keuangan yang baik serta mengetahui produk-produk keuangan. Individu akan mengetahui manfaat dari produkproduk keuangan yang ada dan memahami bagaimana cara menggunakannya. Produk-produk keuangan ini meliputi tabungan, pinjaman, asuransi, dan investasi. Literasi keuangan memberi keterampilan menerapkan pemahaman itu dalam kehidupan sehari-hari untuk mencapai kesuksesan di kemudian hari. Itulah alasan mengapa ada peningkatan kehidupan karena kepuasan yang datang dari finansial literacy yang tinggi. Terdapat empat indikator yang digunakan untuk mengetahui tingkat financial literacy individu, antara lain pengetahuan keuangan pribadi, simpanan atau pinjaman, asuransi dan investasi (Chen \& Volpe, 1998).

\section{Financial Attitude}

Financial attitude adalah pemikiran atau pandangan individu mengenai hal-hal yang berhubungan dengan keuangan yang diterapkan pada sikapnya (Anggraeni, 2019). Financial attitude memiliki 
peran penting dalam menentukan keberhasilan atau kegagalan perilaku finansial. Semakin tinggi sikap keuangan seseorang, maka semakin tinggi pula kesadaran untuk bertanggung jawab atas penggunaan keuangannya, sehingga akan berdampak positif pada perilaku manajemen keuangan. Individu yang memiliki financial attitude yang baik mampu menahan diri dalam melakukan kegiatan konsumsi dan memiliki kontrol yang baik terhadap perilaku keuanggannya. Terdapat enam indikator untuk mengetahui tingkat financial attitude individu, antara lain ketaatan terhadap pola menabung, menentukan tujuan keuangan, tanggung jawab atas kesejahteraan keuangannya, konsentrasi dalam manajemen keuangannya, membuat perencanaan tentang pengeluarannya, membuat rencana tentang keuangan untuk masa depan (Anthony, 2011).

\section{Financial Management Behavior}

Menurut Anggraeni (2019), financial management behavior yaitu keterampilan individu dalam merencanakan, membuat anggaran, melakukan pengelolaan, dan melakukan pengendalian keuangannya. Perilaku pengelolaan keuangan individu bisa dilihat dari bagaimana seseorang itu mengelola uang tunai yang dimiliki, tabungan, hutang dan pengeluaran-pengeluaran lainnya. Individu yang memiliki perilaku manajemen keuangan yang baik akan lebih efektif menggunakan keuangannya, melakukan pengelolaan dan mengendalikan pengeluaran, berinvestasi, dan membayar biaya konsumsi dengan baik. Terdapat lima indikator yang dapat digunakan untuk mengetahui tingkat financial management behavior individu, antara lain tingkatan seseorang dalam mengontrol pengeluaran, membayar tagihan, membuat rencana keuangan, menyediakan dana, dan menyimpan uangnya (Ida \& Dwinta, 2010).

\section{Financial Satisfaction}

Financial satisfaction adalah perasaan puas individu tentang keuangan pribadi (Hasibuan et al., 2018). Individu yang mempunyai kepuasan finansial yaitu seseorang yang telah merasakan kepuasan dengan keadaan keuangan pribadinya. Financial satisfaction ini dapat tercapai apabila seseorang mempunyai sumberdaya keuangan yang memadai untuk memenuhi kebutuhannya. Dari penjelasan tersebut, tercapainya atau tidak tercapainya kepuasan keuangan individu ditentukan oleh bagaimana seseorang melakukan pengelolaan keuangan dalam kehidupan sehari-hari. Terdapat beberapa indikator untuk mengetahui tingkat financial satisfaction seseorang antara sudut pandang pribadi terhadap pendapatannya, mengelola masalah keuangannya, memenuhi kebutuhan dasarnya, tabungan, utang, ketersediaan dana masa depan, dan menetapkan tujuan hidupnya (Hasibuan et al., 2018).

\section{Hubungan antar Variabel}

Theory of Planned Behavior (TPB) mengemukakan bahwa ada tiga faktor yang melatar belakangi individu dalam berperilaku, yaitu personal, sosial, dan informasi (Ajzen, 2005). Dalam hal ini financial literacy termasuk ke dalam faktor informasi. Informasi ini terdiri dari pengetahuan, pemahaman, pencarian, dan dari kejadian yang telah terjadi. Informasi-informasi yang diperoleh seseorang dapat memengaruhi perilaku mereka, misalnya dalam hal perilaku manajemen keuangan. Individu yang memiliki literasi keuangan yang tinggi, maka memiliki pengetahuan atau pemahaman mengenai bagaimana melakukan manajemen keuangan yang baik serta mengetahui produk-produk keuangan. Individu akan mengetahui manfaat dari produk-produk keuangan yang ada dan memahami bagaimana cara menggunakannya (Falahati et al., 2012). Produk-produk keuangan ini meliputi tabungan, pinjaman, asuransi, dan investasi. Menurut Prihartono \& Asandimitra (2018), individu yang mempunyai financial literacy yang tinggi akan mempunyai pemahaman tentang keuangan yang tinggi pula. Pemahaman individu tentang keuangan yang baik memberikan dampak yang baik terhadap perilaku manajmen keuangan individu dalam kegidupan sehari-hari. Pengeloaan keuangan ini meliputi bagamana cara membuat anggaran dan menyusun skala prioritas kebutuhan agar sumber daya keuangan dapat dialokasikan secara tepat sasaran. Menurut Anggraeni (2019), financial literacy berpengaruh terhadap financial management behavior. Hasil yang sama diungkapkan Falahati et al. (2012), financial literacy berpengaruh terhadap financial management behavior. Hasil yang sama juga dikemukakan Prihartono \& Asandimitra (2018). Hasil berbeda diungkapkan oleh Yap et al. (2018) yang mengemukakan financial literacy tidak berpengaruh terhadap financial management behavior. 
Moch. Sigit Prabowo \& Nadia Asandimitra. Faktor yang Memengaruhi Financial Satisfaction Pengguna E-Commerce di Surabaya

H1: Financial literacy berpengaruh terhadap financial management behavior pada pengguna $e$ commerce di Surabaya.

Theory of planned behavior menjelaskan jika landasan individu melakukan sesuatu dipengaruhi faktor-faktor yang melatar belakanginya yaitu attitude towards behavioral, subjective norm, dan perceived behavioral control. Dalam hal ini financial attitude termasuk ke dalam attitude towards behavioral. Attitude towards behavioral dapat diartikan sebagai penilaian seseorang terhadap sesuuatu yang dijadikan landasan atau pedoman bagaimana seseorang tersebut harus berperilaku. Attitude towards behavioral ditentukan oleh keyakinan seseorang mengenai akibat dari sebuah perilaku. Apabila seseorang meyakini bahwa perilaku tersebut memberikan keuntungan, maka keyakinan itu bisa memperkuat sikap seseorang terhadap perilaku itu (Ajzen, 2005). Menurut Anggraeni (2019), financial attitude yang dimiliki individu ini mengacu tentang bagaimana pandangan seseorang terhadap kondisi keuangannya. Pandangan atau pikiran seseorang tentang kondisi keuangan pribadinya akan dijadikan sebagai landasan individu tersebut dalam mengambil tindakan yang tepat. Sikap individu mengenai kondisi keuangan yang dihadapi akan berdampak terhadap perilaku seseorang dalam kegiatan manajmen keuangan yang diterapkan pada kehidupan sehari-hari. Apabila individu mempunyai financial attitude yang baik mampu menahan diri dan mengontrol konsumsi dengan baik (Armilia \& Isbanah, 2020). Menurut Yap et al. (2018), financial attitude berpengaruh terhadap financial management behavior. Hasil sama diungkapkan oleh Armalia (2020). Hasil berbeda diungkapkan Rizkiawati \& Asandimitra (2018) mengemukakan bahwa financial attitude tidak berpengaruh terhadap financial management behavior.

$\mathrm{H} 2$ : Financial attitude berpengaruh terhadap financial management behaviorpada pengguna $e$ commerce di Surabaya.

Teori Subjective Well-Being atau teori kesejahteraan subjektif menjelaskan bahwa terdapat tiga faktor utama yaitu kepuasan, efek menyenangkan dan efek yang tidak menyenangkan. Dalam hal ini financial satisfaction termasuk dalam komponen kepuasan. Subjective Well-Being seseorang berhubungan dengan suatu perasaan atau penilaian seseorang terhadap sesuatu hal yang telah dialami kemudian seseorang tersebut melakukan evaluasi kejadian yang telah terjadi serta menjadiakan pengalaman tersebut sebagai pembelajaran yang positif. Seseorang yang menjalani hidupnya dengan hal-hal yang positif maka akan mencapai suatu kepuasan (Diener et al., 2003). Salah satu contoh dari hal positif itu adalah dengan selalu menambah literasi atau wawasan tentang keuangan. Menurut (Anggraeni \& Tandika, 2019), literasi keuangan memberi keterampilan menerapkan pemahaman itu dalam kehidupan sehari-hari untuk mencapai kesejahteraan di kemudian hari. Pengetahuan keuangan pribadi dibutuhkan seseorang untuk melakukan keputusan yang benar dan menghindari kesalahan ketika melakukan sebuah keputusan tentang keuangannya. Apabila individu yang mampu membuat keputusan yang tepat maka akan merasakan kepuasan keuangan dalam hidupnya. Kebutuhan primer, sekunder, dan tersier seseorang akan terpenuhi apabila seseorang mempunyai tingkat litersi keuangan yang baik. Literasi keuangan yang baik membantu individu dalam mencapai kesejahteraan finansial atau kepuasan keuangan (Hasibuan et al., 2018). Menurut penelitian Candra \& Memarista (2015), financial literacy berpengaruh positif terhadap financial satisfaction. Hasil sama diungkapkan Hasibuan et al. (2018), Ahmad et al. (2017), Falahati et al. (2012), serta Xiao \& Porto (2017). Hasil yang berbeda diungkapkan oleh Yap et al., (2018) yang mengemukakan financial literacy tidak berpengaruh terhadap financial satisfaction.

H3: Financial literacy berpengaruh terhadap financial satisfaction pada pengguna e-commerce di Surabaya.

Menurut teori Subjective Well-Being, kepuasan berhubungan dengan bagaimana seseorang merasakan sesuatu yang telah dialami kemudian seseorang tersebut melakukan evaluasi kejadian yang telah terjadi serta menjadiakan pengalaman tersebut sebagai pembelajaran yang positif. Dalam hal ini, kepuasan seseorang ditentukan oleh sikap dan cara menginterpestasi pengalamannya ke dalam kehidupan sehari-hari. Seseorang yang mempunyai sikap yang baik maka akan mencapai suatu kepuasan (Diener et al., 2003). Menurut Arifin (2018), sikap finansial memiliki peran penting dalam 
menentukan keberhasilan atau kegagalan perilaku finansial seseorang. Sikap keuangan menunjukkan tingkat kecerdasan dalam hal setuju atau tidak setuju yang membantu seseorang dalam mengelola keuangan mereka. Individu yang mempunya financial attitude yang baik cenderung mampu menahan diri dan mampu mengontrol tingkat konsumsi dengan baik. Semakin baik sikap keuangan seseorang, semakin tinggi kesadaran untuk bertanggung jawab atas penggunaan keuangannya, sehingga akan berdampak positif pada perilaku keuangan (Falahati et al., 2012). Itulah alasan mengapa apabila individu mempunyai perilaku manajemen keuangan yang baik maka akan dapat mencapai kepuasan keuangan. Arifin (2018) mengemukakan financial attitude berpengaruh terhadap financial satisfaction. Hasil sama diungkapkan Candra \& Memarista (2015) dan Falahati et al. (2012). Hasil berbeda diungkapkan oleh Armilia \& Isbanah (2020), bahwa financial attitude tidak berpengaruh terhadap financial satisfaction.

H4: Financial attitude berpengaruh terhadap financial satisfaction pada pengguna e-commerce di Surabaya.

Menurut teori Subjective Well-Being, kesejahteraan subjektif yang diperoleh individu bergantung dari bagaimana seseorang merasakan sesuatu yang telah dialami kemudian seseorang tersebut melakukan evaluasi kejadian yang telah terjadi serta menjadiakan pengalaman tersebut sebagai pembelajaran yang positif. Dalam hal ini perilaku seseorang lah yang menentukan apakah seseorang tersebut mampu mencapai kepuasan atau tidak. Seseorang yang mempunyai perilaku yang baik maka akan mencapai kepuasan dalam hidupnya (Diener et al., 2003). Menurut Hasibuan et al. (2018) perilaku manajemen keuangan mempunyai hubungan yang positif dengan tercapainya kesejahteraan individu dan memperoleh kepuasan keuangan. Perilaku manajemen keuangan meliputi penganggaran, pengelolaan, pengendalian, mencari, dan menyimpan uang dalam kehidupan sehari-hari (Halim \& Astuti, 2015). Sehingga individu yang memiliki financial management behavior yang baik, maka tingkat financial satisfaction individu tersebut juga akan semakin tinggi. Menurut Yap et al. (2018) financial management behavior berpengaruh positif terhadap financial satisfaction. Hasil yang sama juga dikemukakan oleh Hasibuan et al. (2018), Coşkuner (2016), Xiao \& Porto (2017), dan Halim \& Astuti (2015).

H5: Financial management behavior berpengaruh terhadap financial satisfaction pada pengguna $e$ commerce di Surabaya.

Individu yang mempunyai pemahaman atau pengetahuan tentang keuangan akan mempunyai keterampilan mengelola keuangannya dan kemudian diterapkan pada kehidupan sehari-hari maka seseorang tersebut akan memperoleh kepuasan keuangan (Ahmad et al., 2017). Financial literacy memberikan pengetahuan dan pemahaman yang membuat seseorang mengetahui bagaimana cara melakukan tindakan keuangan yang tepat atau mengetahui tentang produk-produk keuangan (Humaira \& Sagoro, 2018). Menurut Anggraeni \& Tandika (2019), literasi keuangan memberi keterampilan untuk mengimplementasikan pemahaman itu dalam menjalankan pengelolaan keuangan dengan tepat. Jika individu mempunyai perilaku pengelolaan keuangan yang baik, seseorang tersebut dapat mencapai kepuasan keuangan. Tingkat kepuasan keuangan seseorang akan semakin tinngi jika seseorang tersebut telah mempunyai kemampuan untuk mengelola keuangannya dengan baik. Oleh karena itu, fianancial management behavior dapat memediasi hubungan financial literacy terhadap financial satisfaction (Falahati et al., 2012). Ahmad et al. (2017) mengungkapkan financial management behavior memediasi financial literacy terhadap financial satisfaction. Hasil sama diungkapkan Falahati et al. (2012) bahwa financial management behavior memediasi financial literacy terhadap financial satisfaction.

H6: Financial management behavior memediasi financial literacy terhadap financial satisfaction pada pengguna e-commerce di Surabaya.

Menurut Arifin (2018), financial attitude memiliki peran penting dalam menentukan keberhasilan atau kegagalan perilaku finansial. Sikap keuangan ini meliputi ketaatan terhadap pola menabung, 
menentukan tujuan keuangan, tanggung jawab atas kesejahteraan keuangannya, konsentrasi dalam manajemen keuangannya, membuat perencanaan tentang pengeluarannya, membuat rencana tentang keuangan untuk masa depan. Seseorang jika memiliki financial attitude yang tinggi cenderung mampu menahan diri dalam melakukan kegiatan konsumsi dan memiliki kontrol yang baik terhadap perilaku keuangannya. Semakin tinggi sikap keuangan seseorang, semakin tinggi kesadaran untuk bertanggung jawab atas penggunaan keuangannya, sehingga akan berdampak positif pada perilaku manajemen keuangan (Armilia \& Isbanah, 2020). Jika individu mempunyai perilaku pengelolaan keuangan dengan baik akan mencapai kepuasan keuangan. Tingkat kepuasan keuangan seseorang akan semakin tinngi jika seseorang tersebut telah mempunyai kemampuan financial management behavior yang tinggi. Sehingga, variabel financial management behavior dapat memediasi hubungan antara financial literacy denagn financial satisfaction (Armilia \& Isbanah, 2020). Arifin (2018) mengemukakan financial management behavior memediasi hubungan antara financial attitude terhadap financial satisfaction. Hasil sama juga diungkapkan oleh Armilia \& Isbanah (2020) dan Falahati et al. (2012).

H7: Financial management behavior memediasi financial attitude terhadap financial satisfaction pada pengguna e-commerce di Surabaya.

\section{METODE PENELITIAN}

Penelitian ini termasuk penelitian konklusif kausalitas. Jenis data pada penelitian ini ialah data kuantitatif atau data yang dapat dikonfersikan dalam bentuk angka-angka. Sumber data primer dan data sekunder digunakan untuk penelitian. Data primer diperoleh melalui kuesioner yang disebar di seluruh wilayah Kota Surabaya. Pengisian kuesioner secara online melalui google form yang diberikan kepada responden. Data sekunder diperoleh dari jurnal, buku, artikel ilmiah, dan internet. Data sekunder ini digunakan untuk menyusun landasan teori, menentukan hipotesis, membuat kerangka berpikir, dan menentukan metodologi penelitian yang sesuai.

Populasi penelitian ini ialah pengguna e-commerce di Kota Surabaya. Penelitian ini menggunakan teknik purposive sampling. Kriteria yang digunakan antara lain pengguna e-commerce yang termasuk ke dalam 10 e-commerce teratas yang mendominasi pasar online Indonesia, berdomisili di Kota Surabaya, dan berusia 18 sampai 35 tahun. Rentang usia ini dipilih karena seseorang yang berusia 18 sampai 35 tahun merupakan usia yang mempunyai tingkat literasi keuangan paling tinggi (OJK, 2017). Berdasarkan data dari Iprice (2019), terdapat 10 e-commerce yang mendominasi pasar online Indonesia yaitu Shopee, Lazada, Bukalapak, Tokopedia, JD.id, Blibli.com, Zilingo Shopping, Zalora, Amazon dan AliExpres. Dalam mementukan jumlah sampel adalah menggunakan nilai 9 yang dikalikan dengan jumlah indikator. Jumlah sampel penelitian ini sebanyak 218 responden dengan kriteria yaitu pengguna e-commerce di Surabaya dan berusia 18 sampai 35 tahun.

Skala likert digunakan untuk mengukur jawaban responden mengenai pernyataan yang telah diberikan. Skala likert dapat mengukur respon seseorang mengenai pernyataan-pernyataan yang diberikan menggunakan skor 1 sampai 4. Pada financial literacy dan financial attitude respon yang digunakan adalah sangat setuju, setuju, tidak setuju, dan sangat tidak setuju. Pada financial management behavior respon yang digunakan adalah buruk, wajar, baik, dan sangat baik. Pada variabel financial satisfaction respon yang digunakan adalah sangat puas, cukup puas, kurang puas, dan tidak puas. Skor dari setiap item pernyataan pada masing-masing variabel kemudian dijumlah dan dirata-rata untuk mengetahui bobot jawaban dari responden. Penggolongan skor yang digunakan sebagi dasar untuk interprestasi nilai variabel dengan menggunakan dasar kriteria three box method, dinama nilai terbesar yang digunakan adalah 4 dan nilai terkecil dari skala adalah 1 . Jumlah kelas dalam skala tersebut adalah 3, sehingga akan menghasilkan rentang nilai sebesar 1,00. Sedangkan skala Gutman digunakan untuk mengukur jawaban responden atas pertanyaan yang telah diberikan pada kuesioner. Skala Gutman dipilih dalam penelitian ini karena pada financial literacy juga menggunakan pertanyaan untuk mengukur jawaban dari responden. Apabila jawaban responden benar mendapatkan skor 1, sedangkan jika jawaban dari responden tersebut salah maka mendapatkan skor 0 . Selanjutnya skor tersebut dijumlah dan dirata-rata untuk mengetahui bobot jawaban dari responden. 
Kemudian dilihat apakah tingkat financial literacy masyarakat pengguna e-commerce di Kota Surabaya tergolong dalam kategori tinggi, sedang, atau rendah. Analisis pada penelitian ini menggunakan path analysis model kompleks menggunakan aplikasi AMOS versi 23.

\section{HASIL DAN PEMBAHASAN}

\section{Karakteristik Responden}

Karakteristik responden pada penelitian ini dapat dikelompokkan ke dalam beberapa faktor yaitu usia dan aplikasi e-commerce yang digunakan. Responden dengan usia 18 sampai 25 tahun berjumlah 216 responden dengan persentase yaitu 99\%. Sedangkan responden dengan usia 26 sampai 35 tahun sebanyak 2 responden atau dengan persentase yaitu $1 \%$. Jumlah responden yang menggunakan aplikasi Shopee adalah sebanyak 180 responden atau 87\%, Tokopedia sebanyak 69 responden atau $32 \%$, Lazada sebanyak 50 responden atau 23\%, Bukalapak sebanyak 35 responden atau 16\%, JD.id sebanyak 12 responden atau 6\%, Zalora sebanyak 6 responden atau 3\%, Blibli.com sebanyak 5 responden atau $2 \%$, Amazon sebanyak 5 responden atau 2\%, AliExpres sebanyak 4 responden atau $2 \%$, dan Zilingo Shopping sebanyak 4 responden atau $2 \%$.

\section{Hasil Uji Validitas dan Reliabilitas}

Nilai AVE financial literacy adalah 0,54, financial attitude 0,51, financial management behavior 0,53 dan financial satisfaction 0,53. Nilai akar kuadrat AVE semua variabel lebih tinggi daripada nilai korelasi antar indikator. Indikator-indikator dalam penelitian ini dapat dikatakan valid. Nilai CR dari variabel financial literacy adalah 0,82, financial attitude 0,89, financial management behavior 0,86 dan financial satisfaction 0,94. Semua indikator mempunyai nilai CR lebih dari 0,7. Indikatorindikator dalam penelitian ini dapat dinyatakan reliabel.

\section{Hasil Uji Asumsi (Uji Outlier dan Normalitas)}

Untuk mengetahui data yang outlier dilakukan dengan melihat mahalanobis distance pada output AMOS dengan syarat nilai P2 $\geq 0,001$. Dalam uji outlier ditemukan 103 data yang outlier dan data tersebut harus dihapus. Jumlah data yang dapat digunakan dalam tahap berikutnya yaitu 115 data. Uji normalitas dapat dilihat dari output pada AMOS yakni assesment of normality. Data dinyatakan normal jika critical ratio bernilai di antara -2,58 sampai dengan 2,58. Indikator FS4 mempunyai nilai $-3,912$ lebih dari $-2,58$ dan dapat dinyatakan datanya tidak terdistribusi normal, sehingga harus dihapus.

\section{Hasil Uji Kelayakan Model dan Uji Hipotesis}

Gambar 2 menunjukkan model diagram jalur dalam penelitian ini. Secara keseluruhan, model penelitian menunjukkan 3 hasil yang baik dengan nilai CFI 0,968 >0,900, TLI 0,962 >0,900, dan RMSEA $0,050 \geq 0,050$ dan $\geq 0,080$. Artinya model sudah berada di kondisi yang baik dan bisa dilanjutkan ke tahap selanjutnya.

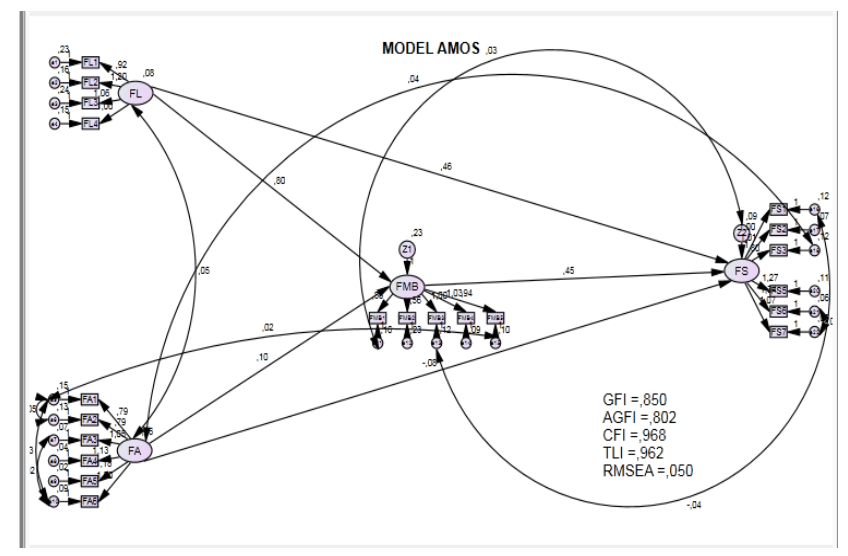

Sumber: Output AMOS

Gambar 2. MODEL DIAGRAM JALUR 
Moch. Sigit Prabowo \& Nadia Asandimitra. Faktor yang Memengaruhi Financial Satisfaction Pengguna E-Commerce di Surabaya

Tabel 1.

HASIL UJI KELAYAKAN MODEL

\begin{tabular}{cccc}
\hline Goodness of Fit Indices & Batas & Hasil & Keterangan \\
\hline GFI & $>0,900$ & 0,850 & Marginal \\
AGFI & $>0,900$ & 0,802 & Marginal \\
CFI & $>0,900$ & 0,968 & Baik \\
TLI & $>0,900$ & 0,962 & Baik \\
RMSEA & $\geq 0,050$ dan $\geq 0,080$ & 0,050 & Baik \\
\hline
\end{tabular}

Sumber: Output AMOS

Tabel 1 menunjukkan hasil uji kelayakan model. Secara keseluruhan, model penelitian menunjukkan 3 hasil yang baik. Artinya model sudah berada di kondisi yang baik dan bisa dilanjutkan ke uji hipotesis.

Tabel2.

HASIL UJI HIPOSTESIS

\begin{tabular}{ccccc}
\hline Variabel & Estimate & S.E. & C.R. & P \\
\hline FMB $\leftarrow$ FL & 0,820 & 0,333 & 2,461 & 0,014 \\
FMB $\leftarrow$ FA & 0,072 & 0,163 & 0,441 & 0,659 \\
FS $\leftarrow$ FA & $-0,095$ & 0,098 & $-0,967$ & 0,334 \\
FS $\leftarrow$ FL & 0,493 & 0,221 & 2,235 & 0,025 \\
FS $\leftarrow$ FMB & 0,447 & 0,088 & 5,086 & 0,001 \\
\hline
\end{tabular}

Sumber: Output AMOS

Tabel 2 menunjukkan hasil uji hipotesis. Dengan melihat tabel di atas dapat diketahui bahwa H1 diterima karena memiliki nilai P 0,014, H2 ditolak karena memiliki nilai P 0,659, H3 diterima karena memiliki nilai P 0,025, H4 ditolak karena memiliki nilai P 0,334, dan H5 diterima karena memiliki nilai P 0,001 .

\section{Hasil Uji Mediasi}

Untuk mengukur uji mediasi dalam penelitian ini menggunakan bantuan kalkulator sobel test yang dapat diakses melalui internet dengan syarat $\mathrm{p} \leq 0,05$. Hasil penelitian ini menyatakan bahwa variabel financial management behavior mampu memediasi financial literacy terhadap financial satisfaction dengan nilai p 0,026. Variabel financial management behavior tidak memediasi financial attitude terhadap financial satisfaction dengan nilai p 0,659 .

\section{Pengaruh Financial Literacy terhadap Financial Management Behavior}

Financial literacy berpengaruh terhadap financial management behavior. Sehingga hipotesis diterima. Hasil penelitian ini sesuai dengan Theory of Planned Behavior yang menjelaskan ada komponen yang melatarbelakangi seseorang berperilaku, antara lain personal, sosial, dan informasi. Dalam hal ini financial literacy termasuk ke dalam faktor informasi. Informasi ini terdiri dari pengetahuan, pemahaman, pencarian, dan dari kejadian yang telah terjadi. Informasi-informasi yang diperoleh seseorang dapat memengaruhi perilaku mereka, misalnya dalam hal perilaku manajemen keuangan. Individu yang mempunyai literasi keuangan yang tinggi, memiliki pengetahuan atau pemahaman mengenai bagaimana melakukan manajemen keuangan yang baik serta mengetahui produk-produk keuangan. Individu akan mengetahui manfaat dari produk-produk keuangan yang ada dan memahami bagaimana cara menggunakannya. Produk-produk keuangan ini meliputi tabungan, pinjaman, asuransi, dan investasi. Individu yang mempunyai financial literacy yang tinggi akan mempunyai pemahaman tentang keuangan yang tinggi pula. Pemahaman individu tentang keuangan yang tepatdapat memberikan dampak yang baik terhadap perilaku manajmen keuangan individu dalam kegidupan sehari-hari. Pengeloaan keuangan ini meliputi bagamana cara membuat anggaran dan menyusun skala prioritas kebutuhan agar sumberdaya keuangan dapat dialokasikan secara tepat sasaran. Jadi apabila seseorang mempunyai financial literacy yang baik maka akan memiliki financial 
management behavior yang baik pula. Tingkat lierasi keuangan dan financial management behavior pengguna e-commerce di Kota Surabaya tergolong dalam katergori sedang. Hal ini menunjukkan bahwa tingkat pengetahuan keuangan pribadi, simpanan/pinjaman, asuransi, dan investasi responden cukup baik. kemampuan responden dalam mengontrol pengeluaran, merencanakan keuangan di masa depan, dan menyimpan uang juga cukup baik. Hasil penelitian ini sejalan dengan penelitan Anggraeni (2019), Falahati et al. (2012), dan Prihartono \& Asandimitra (2018).

\section{Pengaruh Financial Attitude terhadap Financial Management Behavior}

Financial attitude tidak berpengaruh terhadap financial management behavior. Sehingga hipotesis ditolak. Hasil penelitian ini tidak sesuai dengan Theory of planned behavior yang menjelaskan jika landasan individu melakukan sesuatu dipengaruhi faktor-faktor yang melatar belakanginya yaitu attitude towards behavioral, subjective norm, dan perceived behavioral control. Dalam hal ini financial attitude termasuk ke dalam attitude towards behavioral. Attitude towards behavioral dapat diartikan sebagai penilaian seseorang terhadap sesuuatu yang dijadikan landasan atau pedoman bagaimana seseorang tersebut harus berperilaku. Attitude towards behavioral ditentukan oleh keyakinan seseorang mengenai akibat dari sebuah perilaku. Apabila seseorang meyakini bahwa perilaku tersebut memberikan keuntungan, maka keyakinan itu bisa memperkuat sikap seseorang terhadap perilaku itu. Hasil yang tidak berpengaruh ini sidebabkan oleh mayoritas responden adalah pengguna e-commerce berumur 18 - 25 tahun. Rentang usia tersebut dapat dikatakan usia yang masih belum sepenuhnya dapat mengelola keuangan pribadi mereka dengan sangat baik. Mereka mempunyai financial attitude yang sangat baik tetapi belum sepenuhnya diterapkan pada pengelolaan keuangannya. Hal ini mengungkapkan apabila seseorang memiliki tingkat financial attitude yang tinggi belum tentu mempunyai financial management behavior yang tinggi. Tingkat financial attitude pengguna e-commerce di Kota Surabaya tergolong dalam kategori tinggi. Hal ini menunjukkan bahwa sikap responden terhadap pola menabung, menentukan pembelanjaan yang prioritas, dan tanggung jawab atas kesejahteraan keuangan sangat baik. Sedangkan tingkat financial management behavior pengguna e-commerce di Kota Surabaya tergolong dalam kategori sedang. Hal ini menunjukkan bahwa kemampuan responden dalam mengontrol pengeluaran, merencanakan keuangan di masa depan, dan menyimpan uang cukup baik. Hasil penelitian ini sejalan dengan penelitian Rizkiawati \& Asandimitra (2018).

\section{Pengaruh Financial Literacy terhadap Financial Satisfaction}

Financial literacy berpengaruh terhadap financial satisfaction. Sehingga dalam penelitian ini hipotesis diterima. Hasil penelitian ini sesuai dengan teori Subjective Well-Being atau teori kesejahteraan subjektif yang menjelaskan bahwa terdapat tiga faktor utama yang berhubungan dengan kesejahteraan subjektif yaitu kepuasan, efek menyenangkan dan efek yang tidak menyenangkan. Dalam hal ini financial satisfaction termasuk dalam komponen kepuasan. Subjective Well-Being berkaitan tentang bagaimana individu menilai sesuatu yang telah dialami kemudian seseorang tersebut melakukan evaluasi kejadian yang telah terjadi serta menjadiakan pengalaman tersebut sebagai pembelajaran yang positif. Seseorang yang menjalani hidupnya dengan hal-hal yang positif maka akan mencapai suatu kepuasan. Salah satu contoh dari hal positif itu adalah dengan selalu menambah literasi atau wawasan tentang keuangan memberi keterampilan menerapkan pemahaman itu dalam kehidupan sehari-hari untuk mencapai kesejahteraan di kemudian hari. Pengetahuan keuangan pribadi dibutuhkan seseorang untuk melakukan keputusan yang benar dan menghindari kesalahan ketika melakukan sebuah keputusan tentang keuangannya. Apabila individu yang mampu membuat keputusan yang tepat maka akan merasakan kepuasan keuangan dalam hidupnya. Kebutuhan primer, sekunder, dan tersier seseorang akan terpenuhi apabila seseorang mempunyai tingkat litersi keuangan yang baik. Literasi keuangan yang baik membantu individu dalam mencapai kesejahteraan finansial atau kepuasan keuangan. Jadi seseorang yang memiliki financial literacy yang tinggi maka akan memiliki financial satisfaction yang tinggi pula. Tingkat financial literacy dan kepuasan keuangan pengguna e-commerce di Kota Surabaya tegolong dalam kategori sedang. Hal ini menunjukkan bahwa tingkat pengetahuan keuangan pribadi, simpanan/pinjaman, asuransi, dan investasi responden cukup baik, serta ingkat kepuasan keuangan responden juga cukup baik. Hasil penelitian ini sesusai dengan 
Moch. Sigit Prabowo \& Nadia Asandimitra. Faktor yang Memengaruhi Financial Satisfaction Pengguna E-Commerce di Surabaya

penelitian Candra \& Memarista (2015), Hasibuan et al. (2018), Ahmad et al. (2017), Falahati et al. (2012) dan Xiao \& Porto (2017).

\section{Pengaruh Financial Attitude terhadap Financial Satisfaction}

Financial attitude tidak berpengaruh terhadap financial satisfaction. Sehingga hipotesis ditolak. Hasil penelitian ini tidak sesuai dengan teori Subjective Well-Being yang menjelaskan bahwa kepuasan berhubungan dengan bagaimana seseorang merasakan sesuatu yang telah dialami kemudian seseorang tersebut melakukan evaluasi kejadian yang telah terjadi serta menjadiakan pengalaman tersebut sebagai pembelajaran yang positif. Dalam hal ini, kepuasan seseorang ditentukan oleh sikap dan cara menginterpestasi pengalamannya ke dalam kehidupan sehari-hari. Hasil yang tidak sesuai ini karena mayoritas responden merupakan pengguna e-commerce yang berumur 18 - 25 tahun. Pada usia tersebut dapat dikatakan usia yang masih belum mempunyai penghasilan sendiri atau tingkat penghasilan mereka tidak terlalu tinggi, sehingga tingkat kepuasan terhadap keuangan juga tidak terlalu tinggi. Walaupun seseorang mempunyai sikap terhadap pola menabung, menentukan pembelanjaan yang prioritas, dan tanggung jawab atas kesejahteraan keuangan yang sangat baik tetapi jika tidak ditunjang dengan penghasilan yang tinggi maka seseorang tersebut belum bisa mencapai kepuasan keuangan. Jadi apabila seseorang mempunyai tingkat financial attitude yang tinggi belum tentu seseorang tersebut memiliki financial satisfaction yang tinggi. Tingkat financial attitude pengguna e-commerce di Kota Surabaya tegolong dalam kategori tinggi. Hal ini menunjukkan bahwa sikap responden terhadap pola menabung, menentukan pembelanjaan yang prioritas, dan tanggung jawab atas kesejahteraan keuangan sangat baik. Sedangkan tingkat financial satisfaction pengguna $e-$ commerce di Kota Surabaya tergolong dalam kategori sedang. Hal ini menunjukkan bahwa tingkat kepuasan terhadap pendapatan, memenuhi kebutuhan dasar, tabungan dan pinjaman yang dimiliki, dan keserdiaan uang untuk masa depan responden tidak terlalu tinggi. Hasil penelitian ini sejalan dengan penelitan Armilia \& Isbanah (2020).

\section{Pengaruh Financial Management Behavior terhadap Financial Satisfaction}

Financial management behavior berpengaruh terhadap financial satisfaction. Sehingga hipotesis diterima. Hasil ini penelitian ini sesuai dengan teori Subjective Well-Being yang menjelaskan bahwa kepuasan yang diperoleh bergantung dari bagaimana seseorang merasakan sesuatu yang telah dialami kemudian seseorang tersebut melakukan evaluasi kejadian yang telah terjadi serta menjadiakan pengalaman tersebut sebagai pembelajaran yang positif. Dalam hal ini perilaku seseorang lah yang menentukan apakah seseorang tersebut mampu mencapai kepuasan atau tidak. Seseorang yang mempunyai perilaku yang baik maka akan mencapai kepuasan dalam hidupnya. Perilaku manajemen keuangan yang tepat akan dapat menghasilkan dampak yang baik terhadap kesejahteraan individu dan memperoleh kepuasan keuangan. Perilaku manajemen keuangan ini meliputi penganggaran, pengelolaan, pengendalian, mencari, dan menyimpan uang dalam kehidupan sehari-hari. Sehingga individu yang mempunyai tingkat financial management behavior yang tinggi maka semakin tinggi pula financial satisfaction yang dimiliki oleh seseorang. Tingkat perilaku manajemen keuangan pengguna e-commerce di Kota Surabaya tergolong dalam kategori sedang. Hal ini menunjukkan bahwa kemampuan responden dalam mengontrol pengeluaran, merencanakan keuangan di masa depan, dan menyimpan uang cukup baik. Tingkat kepuasan keuangan pengguna e-commerce di Kota Surabaya juga tergolong dalam kategori sedang. Hal ini menunjukkan bahwa tingkat kepuasan keuangan responden cukup baik. Hasil penelitian ini sejalan dengan penelitan Yap et al. (2018), Hasibuan et al. (2018), Coşkuner (2016), Xiao \& Porto (2017), dan Halim \& Astuti (2015).

\section{Peran Financial Management Behavior Memediasi Financial Literacy terhadap Financial Satisfaction}

Financial management behavior mampu memediasi financial literacy terhadap financial satisfaction. Sehingga hipotesis dapat diterima. Hal ini sesuai dengan teori Subjective Well-Being atau teori kesejahteraan subjektif yang menjelaskan bahwa terdapat tiga komponen utama dari Subjective WellBeingyaitu kepuasan, afek menyenangkan, dan afek yang tidak menyenangkan. Dalam hal ini financial satisfaction termasuk dalam komponen kepuasan. Subjective Well-Being berkaitan dengan kecenderungan seseorang mengevaluasi dan menginterprestasikan pengalamannya secara positif. Seseorang yang menjalani hidupnya dengan hal-hal yang positif maka akan mencapai suatu kepuasan. 
Salah satu contoh dari hal positif itu adalah dengan selalu menambah literasi atau wawasan tentang keuangan. Financial literacy memberikan pengetahuan dan pemahaman yang membuat seseorang mengetahui bagaimana cara melakukan tindakan keuangan yang tepat atau mengetahui tentang produk-produk keuangan. Literasi keuangan memberi keterampilan untuk menerapkan pengetahuan itu untuk melakukan pengelolaan keuangan dengan tepat. Apabila individu memiliki tingkat perilaku manajemen keuangan yang tinggi, maka akan mencapai kepuasan keuangan. Individu yang memiliki pemahaman tentang keuangan, kemudian mempunyai keterampilan mengelola keuangannya yang diterapkan pada kehidupan sehari-hari maka akan memperoleh kepuasan keuangan. Tingkat kepuasan keuangan seseorang akan semakin tinngi jika seseorang tersebut telah mempunyai kemampuan financial management behavior yang baik. Dengan demikian, fianancial management behavior memediasi financial literacy terhadap financial satisfaction. Hasil penelitian sejalan dengan penelitan Ahmad et al. (2017) dan Falahati et al. (2012)

\section{Peran Financial Management Behavior Memediasi Financial Attitude terhadap Financial Satisfaction}

Financial management behavior tidak memediasi financial attitude terhadap financial satisfaction. Sehingga hipotesis ditolak. Hasil penelitian ini tidak sesuai dengan teori Subjective Well-Being yang menjelaskan bahwa kepuasan berkaitan dengan kecenderungan seseorang mengevaluasi pengalamannya secara positif. Dalam pendekatan ini, pengukuran Subjective Well-Being dapat dikaitkan dengan sifat atau kepribadian, sikap, dan cara seseorang menginterprestasi pengalaman hidup. Seseorang yang mempunyai sikap yang baik maka akan mencapai suatu kepuasan. Hasil yang berbeda ini terjadi karena beberapa faktor. Dilihat dari data responden, mayoritas responden adalah pengguna e-commerce berumur 18 - 25 tahun. Rentang usia tersebut dapat dikatakann usia yang masih belum sepenuhnya mampu memanajemen keuangan pribadi dengan sangat baik. Mereka mempunyai sikap keuangan yang baik tetapi tidak sepenuhnya diterapkan pada perilaku pengelolaan keuangannya. Hal ini mengengkapkan apabila seseorang mempunyai tingkat financial attitude yang tinggi belum tentu mempunyai tingkat financial management behavior yang tinggi. Pada rentang usia tersebut juga tergolong usia yang masih belum mempunyai penghasilan sendiri atau tingkat penghasilan mereka tidak terlalu tinggi, sehingga tingkat kepuasan terhadap keuangan juga tidak terlalu tinggi. Walaupun seseorang mempunyai sikap terhadap pola menabung, menentukan pembelanjaan yang prioritas, dan tanggung jawab atas kesejahteraan keuangan yang sangat baik tetapi jika tidak ditunjang dengan penghasilan yang tinggi maka seseorang tersebut belum bisa mencapai kepuasan keuangan. Financial management behavior tidak mampu menjadi variabel mediasi pada financial attitude terhadap financial satisfaction seseorang karena sikap keuangan tidak sepenuhnya diterapkan pada kehidupan sehari-hari. Sehingga mengakibatkan individu belum mampu mencapai kepuasan keuangan. Sikap sangat baik yang tidak sepenuhnya memengaruhi individu mempunyai perilaku manajemen keuangan yang baik. Jika seseorang mempunyai tingkat financial attitude yang tinggi belum tentu seseorang tersebut dapat mencapai kepuasan keuangan.

\section{KESIMPULAN}

Financial literacy berpengaruh terhadap financial management behavior. Financial attitude tidak berpengaruh terhadap financial management behavior karena mayoritas responden berumur $18-25$, usia yang masih belum sepenuhnya mampu memanajemen keuangan mereka dengan baik. Financial literacy dan financial management behavior berpengaruh terhadap financial satisfaction. Financial attitude tidak berpengaruh terhadap financial satisfaction karena responden tergolong usia yang masih belum mempunyai penghasilan sendiri atau tingkat penghasilan mereka tidak terlalu tinggi, sehingga tingkat kepuasan terhadap keuangan juga tidak terlalu tinggi. Financial management behavior mampu memediasi financial literacy terhadap financial satisfaction. Financial management behavior tidak memediasi financial attitude terhadap financial satisfaction karena responden mempunyai sikap keuangan yang sangat baik tetapi tidak sepenuhnya diterapkan pada perilaku manajemen keuangan. 
Moch. Sigit Prabowo \& Nadia Asandimitra. Faktor yang Memengaruhi Financial Satisfaction Pengguna E-Commerce di Surabaya

Keterbatasan dalam penelitian ini adalah kurangnya variasi variabel independen yang digunakan, terbatasnya lokasi penelitian, dan keterbatasan sampel penelitian. Saran untuk masyarakat khususnya para pengguna e-commerce di Kota Surabaya sebaiknya selalu meningkatkan litersi keuangan. Masyarakat sebaiknya juga menerapkan sikap dan literasi keuangan pada perilaku menajemen keuangan. Bagi Otoritas Jasa Keuangan (OJK) hendaknya secara rutin memberikan sosialisai kepada masyarakat mengenai literasi keuangan, sikap keuangan, dan perilaku manajemen keuangan. Penelitian selanjutnya disarankan untuk menggunakan model yang berbeda dengan menggunakan variabel yang belum digunakan pada penelitian ini, misalnya incomel pendapatan, usia, financial knowledge memperluas populasi atau menggunakan objek yang berbeda, misalnya pada pekerja atau karyawan.

\section{DAFTAR PUSTAKA}

Ahmad, K. A. K., Hassan, R., \& Idris, F. (2017). Influence of Financial Literacy on Financial Satisfaction with Financial Behavior as Moderating Variable. Asian Journal of Technical Voational Education And Training, 2, 1-9. https://doi.org/ISSN 0128-0600

Ajzen, I. (2005). Attitudes, Personality and Behavior. International Journal of Strategic Innovative Marketing, Vol. 3, p. 117. https://doi.org/10.1080/08870446.2011.613995

Anggraeni, A. A., \& Tandika, D. (2019). Pengaruh Financial Attitude dan Financial Knowledge terhadap Financial Management Behavior. JEMMA | Journal of Economic, Management and Accounting, 2(2), 9. https://doi.org/10.35914/jemma.v2i2.243

Arifin, A. Z. (2018). Influence Factors Toward Financial Satisfaction with Financial Behavior as Intervening Variable on Jakarta Area Workforce. European Research Studies Journal, 21(1), 90-103. https://doi.org/11082976

Armilia, N., \& Isbanah, Y. (2020). Faktor yang Memengaruhi Kepuasan Keuangan Pengguna Financial Technology di Surabaya. Jurnal Ilmu Manajemen, 8(2018), 39-50. https://doi.org/2549-192X

BPS Jatim. (2019). Pengeluaran Perkapita Pertahun yang Disesuaikan Penduduk Jawa Timur. Retrieved November 15, 2019, from jatim.bps.go.id

Candra, J. W., \& Memarista, G. (2015). Faktor-Faktor yang Mempengaruhi Financial Satisfaction pada Mahasiswa Universitas Kristen Petra. Finesta, 3(2), 1-6.

Chen, H., \& Volpe, R. P. (1998). An Analysis of Personal Financial Literacy Among College Students. Zhongguo Jiguang/Chinese Journal of Lasers, 43(8), 107-128. https://doi.org/10.3788/CJL201643.0811001

Coşkuner, S. (2016). Understanding Factors Affecting Financial Satisfaction: The Influence of Financial Behavior, Financial Knowledge and Demographics. Imperial Journal of Interdisciplinary Research, 2(5), 2454-1362. https://doi.org/ISSN: 2454-1362, $\mathrm{http}: / / \mathrm{www} . o n l i n e j o u r n a l . i n$

Diener, E., Oishi, S., \& Lucas, R. E. (2003). Personality, Culture, and Subjective Well-Being: Emotional and Cognitive Evaluations of Life. Journal, Annual Review of Psychology, 54, 403425 .

Falahati, L., Sabri, M. F., \& Paim, L. H. J. (2012). Assessment a Model of Financial Satisfaction Predictors: Examining the Mediate Effect of Financial Behaviour and Financial Strain. World Applied Sciences Journal, 20(2), 190-197. https://doi.org/10.5829/idosi.wasj.2012.20.02.1832 
Google, Temasek, \& Bain \& Company. (2019). e-Conomy SEA 2019. Retrieved from https://www.temasek.com.sg/en/news-and-views/subscribe/google-temasek-e-conomy-sea2019

Halim, Y. K. E., \& Astuti, D. (2015). Financial Stressors, Financial Behavior, Risk Tolerance, Financial Solvency, Financial Knowledge, dan Kepuasan Finansial. Jurnal Finesta, 3(1), 1923. https://doi.org/10.1109/EDOC.2009.26

Hasibuan, B. K., HR, W. A., \& Lubis, Y. M. (2018). Financial Literacy and Financial Behavior as a Measure of Financial Satisfaction. Advances in Economics, Business and Management Research (AEBMR), 46(Ebic 2017), 503-507. https://doi.org/10.2991/ebic-17.2018.79

Humaira, I., \& Sagoro, E. M. (2018). Pengaruh Pengetahuan Keuangan, Sikap Keuangan, dan Kepribadian terhadap Perilaku Manajemen Keuangan pada Pelaku UMKM Sentra Kerajinan Batik Kabupaten Bantul. Nominal, Barometer Riset Akuntansi Dan Manajemen, 7(1). https://doi.org/10.21831/nominal.v7i1.19363

Ida, \& Dwinta, C. Y. (2010). Pengaruh Locus Of Control, Financial Knowledge, Income terhadap Financial Management Behavior. Jurnal Bisnis Dan Akuntansi, 12(3), 131-144. https://doi.org/10.34208/jba.v12i3

Iprice. (2019). Peta E-Commerce Indonesia. Retrieved October 11, 2019, from http://www.google.com/amp/s/iprice.co.id/insights/mapofecommerce/

OJK. (2017). OJK: Indeks Literasi Dan Inklusi Keuangan Meningkat. Ojk, 1-6. Retrieved from https://www.ojk.go.id/id/berita-dan-kegiatan/siaran-pers/Pages/Siaran-Pers-OJK-Indeks-

Literasi-dan-Inklusi-Keuangan-Meningkat.aspx

Priceza. (2018). 5 Cities in Indonesia with the Most Active Online Shoppers. Retrieved November 10, 2019, from http://www.pricezagroup.com/2018/behavior-indonesian-online-consumers/

Prihartono, M. R. D., \& Asandimitra, N. (2018). Analysis Factors Influencing Financial Management Behaviour. International Journal of Academic Research in Business and Social Sciences, 8(8), 308-326. https://doi.org/10.6007/ijarbss/v8-i8/4471

R.Anthony, P., \& A, R. (2011). Knowledge, Attitude, Practice and Satisfaction on Personal Financial Management Among the Medical Practitioners in the Public and Private Medical Services in Malaysia. International Journal of Business and Management, 6(8), 105-113. https://doi.org/10.5539

Rizkiawati, N. L., \& Asandimitra, N. (2018). Pengaruh Demografi, Financial Knowledge, Financial Attitude, Locus of Control dan Financial Self-Efficacy terhadap Financial Management Behavior Masyarakat Surabaya. Jurnal Ilmu Manajemen (JIM), 6(3). https://doi.org/2549-192X

Vpnmentor.com. (2019). B2C Ecommerce Sales Growth Worldwide. Retrieved October 25, 2019, from https://www.google.com/amp/s/id.vpnmentor.com/amp/blog/trend-internet-vital/espv=1

Xiao, J. J., \& Porto, N. (2017). Financial education and financial satisfaction: Financial literacy, behavior, and capability as mediators. International Journal of Bank Marketing, 35(5), 805817. https://doi.org/10.1108/IJBM-01-2016-0009

Yap, R. J. C., Komalasari, F., \& Hadiansah, I. (2018). The Effect of Financial Literacy and Attitude on Financial Management Behavior and Satisfaction. Bisnis \& Birokrasi Journal, 23(3). https://doi.org/10.20476/jbb.v23i3.9175 